\title{
Managing information on the physical education research field: Bibliometric analysis
}

\author{
Mateusz Tomanek ${ }^{\mathrm{CDE}}$, Andrzej Lis ${ }^{\mathrm{ABCD}}$ \\ Nicolaus Copernicus University in Toruń, Poland
}

Authors contribution: A - Study design; B - Data collection; C - Bibliometric analysis; D - Manuscript preparation; E - Funds collection

\section{Abstract}

Purpose:

Material:

Results:

Conclusions:

\section{Keywords:}

The aim of the study is to assess the development of scientific production and to map thematic coverage of research in physical education. The research process is focused on the following study questions: (1) how has the research productivity developed in the physical education research field?, (2) who are the main contributors (countries, universities, authors, source titles) to the amassing research output in the field?, (3) what are the leading thematic areas attracting the most attention of the academia?, (4) what are the emerging topics in the research field?

The Scopus database was used as a source of bibliometric data for the research sampling process. The research sample $(\mathrm{N}=9,224)$ consisted of the publications including the phrase 'physical education' in their titles. In order to achieve the aim of the study, we employed bibliometric methods i.e. research profiling and keywords co-occurrence analysis. We conducted general publication profiling to assess the trends in scientific production and to recognize leading contributors to the research field. We applied keywords cooccurrence analysis in order to identify and explore major thematic areas as well as emerging topics within the research field. VOSviewer software was used to support the analysis process and visualize the findings.

The study shows that physical education is a well-established research field with a long tradition. In the 2010s, it has received an increasing attention of academia which resulted in breakthrough growth in the number of publications indexed in Scopus. The amassing research output is distributed over 26 subject areas. Social Sciences, Medicine and Health Professions are the subject areas grouping the highest number of publications. The leading contributors to the research field are: the most productive country - the United States, the most productive research institution - Loughborough University, the United Kingdom, the most prolific author - David Kirk from the University of Strathclyde, the United Kingdom, the first choice source title - Teoriya i Praktika Fizicheskoy Kultury. Within the physical education research field, there are identified five leading thematic clusters related to: (1) physical education didactics, (2) physical activity of school pupils, (3) physical education of adolescents, (4) human motor competence, (5) physical activity of adults. Emerging topics include the following issues: (1) physical education teachers and their training/education, (2) physical education in the tertiary education context, (3) physical education in the secondary education context.

The study contributes to better understanding of development patterns in research on physical education. It provides an added value for managing information on scientific productivity in the research field. Through discovering leading thematic areas and emerging topics within the research field, the study points out the issues important both for further research and development of theory as well as for educational and business practice.

physical education, information management, bibliometrics, research profiling, keywords co-occurrence analysis.

\section{Introduction}

Due to its role for human development, physical education, defined as "that part of education which promotes learning through movement" [1] (p. 7), has been attracting a growing interest of academia, which resulted in an amassing scientific output. Physical education is found to be a multifaceted research field, combining the research work from various disciplines including primarily medicine, natural sciences, mainly biological sciences, and pedagogy [2]. Recently, the scope of the physical education research field has been expanded beyond the studies of physical activity to include as well health eating behaviors. In literature, physical training is more and more often considered in the context of physical literacy [3-6] i.e. "teaching and learning of the

\footnotetext{
(c) Mateusz Tomanek, Andrzej Lis, 2020

doi:10.15561/20755279.2020.0404
}

skills, knowledge, attitudes, and behaviors that enhance the responsibility for engagement in lifelong lifestyles" [7] (p. 123). The developments in physical education are a hot topic of the debate in the media [8]. Similarly, in recent years, the dynamic increase in research on various aspects of physical education has been observed in academia. Nevertheless, this amassing production has not been thoroughly mapped and profiled with bibliometric methods.

For instance, Fan and Gan [9] (p. 193) analyze "chronological distribution, journal distribution, supporting from the funds and the keywords" of journal articles on physical education published between 2005 and 2009. However, due to the dynamic development of the research field and limited scope of the analysis, this publication does not provide the comprehensive and up-to-date bibliometric profiling of the field. Hinojo- 
Lucena and associates [10] explore scientific production published prior to 2017 and indexed in the Web of Science database. Nevertheless, this analysis is limited to chronological distribution and general publication profiling only, focusing on statistical analysis of impact of scientific journals and contributions made by research institutions and authors. In consequence, a gap within the body of knowledge may be indicated, to be filled by this study. Therefore, the aim of the paper is to assess the development of scientific production and to map thematic coverage of research in physical education. The research process is focused on the following study questions: (1) how has the research productivity changed in the physical education research field?, (2) who are the main contributors (countries, universities, authors, source titles) to the amassing research output in the field?, (3) what are the leading thematic areas attracting the most attention of the academia?, (4) what are the emerging topics in the research field?

\section{Material and Methods}

\section{Sources}

We used the Scopus database as a source of bibliometric data for the research sampling process. On 05 January 2020, we searched for the phrase 'physical education' in the titles of publications and retrieved 9,224 items. Journal articles are the majority of document types in the sample (84\%). They are followed by: conference papers, reviews and book chapters. In regard to the language of publication, English has a dominant position - $79 \%$ of the items are written in English. Nevertheless, a visible representation of other languages should be noticed including Spanish, Portuguese, and Russian each of them constituting more than $6 \%$ of the research output. The detailed parameters of the research sample are provided in Table 1.

\section{Research Design}

In order to validate the aforementioned observation, we searched for the following combination of phrases in the Scopus and Web of Science databases as of 05 January 2020: Title Search ('physical education') AND ('bibliometric' OR 'bibliometrics' OR 'scientometrics' OR 'informetrics'). In result, we found 19 publications indexed in Scopus, and 19 of them indexed in Web of
Science. After removing duplicates, there are found 22 publications fulfilling the search criteria, which may be grouped into five categories.

The first category covers the bibliometric studies of contributions to the physical education research field (or its sub-fields) made by academic institutions or scholars in Brazil [11, 12], Colombia [13], Poland [14-16] and Spain $[11,12,17,18]$. The second category deals with the topics or research methods included in theses/ dissertations of physical education students in Chile [19], Iran [20] and Poland [21]. The third category provides the assessment of research productivity in journals such as Citius, Altius, Fortius [22] and Movimento [23] The fourth category focuses on some particular narrow topics such as: teaching content in physical education [24], gamification in teaching physical education [25], virtual reality in physical education [26], school physical education in Brazil [27], assessment of physical education in the Brazilian context [28], women's football and futsal [29], or human body [30]. The fifth category makes an attempt to conduct bibliometric analysis of the whole physical education research field.

In order to achieve the aim of the study, we employed bibliometric methods i.e. research profiling [31] and keywords co-occurrence analysis, which is a kind of coword analysis [32]. We conducted general publication profiling in order to identify leading contributors to the research field (i.e. countries, research institutions, journals, authors). Instead of a traditional topic profiling [33-35], we followed the benchmarks of other bibliometric studies $[36,37]$ and applied keywords co-occurrence analysis to assess the trends in scientific production and to identify and explore major thematic areas as well as emerging topics within the research field. VOSviewer software, developed by the researchers of Leiden University [38, 39], was used to support the analysis process and visualize the findings.

\section{Keywords Co-occurrence Analysis}

The publications in the research sample provide 13,926 keywords. 'Physical education' with 4,364 occurrences is the most cited expression. The threshold of 1,000 occurrences is achieved by 4 publications, 500 occurrences - by 13 of them, 100 - by 66 publications. There are 9,668 keywords which occurred only once.

Table 1. Parameters of the research sample

\begin{tabular}{|c|c|}
\hline Category & Items (N) \\
\hline $\begin{array}{l}\text { Document } \\
\text { type }\end{array}$ & $\begin{array}{l}\text { Article (7,767); Conference Paper (365); Review (349); Book Chapter (342); Note (153); Editorial } \\
\text { (88); Book (60); Letter (41); Erratum (28); Short Survey (9); Retracted (1); Undefined (21) }\end{array}$ \\
\hline Language & $\begin{array}{l}\text { English (7,313); Spanish (587); Portuguese (565); Russian (563); French (168); German (123); } \\
\text { Croatian (46); Polish (43); Czech (40); Chinese (21); Turkish (21); Italian (15); Lithuanian (11); Korean } \\
\text { (8); Japanese (7); Serbian (7); Norwegian (6); Romanian (6); Slovenian (6); Catalan (6), Slovak (4), } \\
\text { Swedish (4), Dutch (3); Arabic (2); Bosnian (2) Hungarian (2); Moldavian (2); Moldovan (2); Hebrew } \\
\text { (2); Ukrainian (1); Undefined (33) }\end{array}$ \\
\hline
\end{tabular}

Source: Own study based on data retrieved from the Scopus (05 January 2020). 
Table 2.VOSviewer parameters used for analysis

\begin{tabular}{ll}
\hline Item & Characteristic/ value \\
\hline Type of analysis & Co-occurrence analysis \\
Unit of analysis & All keywords \\
Counting method & Full counting \\
Method of normalization of strength of the links between items & Association strength method \\
Layout & \\
$\quad$ Attraction & 2 (default setting) \\
$\quad$ Repulsion & 0 (default setting) \\
$\begin{array}{l}\text { Clustering } \\
\text { Resolution parameter (detail of clustering) }\end{array}$ & \\
Minimum cluster size [N] & 1 (default setting) \\
Merging small clusters & 1 (default setting) \\
Visualization & Switched on \\
Scale & \\
Weights & 1.00 \\
Labels size & occurrences \\
Maximum number of lines & 0.50 \\
High frequency keywords used for analysis [N] & 1000 \\
Minimum occurrences of a keyword used for analysis [N] & 139 \\
\hline
\end{tabular}

Source: Own study.

Therefore, the number of high-frequency keywords to be taken for co-occurrence analysis, calculated according to the formula provided by Donohue [40] as cited by Guo and associates [36], equals to 139, which corresponds to 48 occurrences. The parameters of VOSviewer application used for keywords co-occurrence are presented in Table 2.

\section{Results}

Physical education: Research productivity and general publication profiling

The earliest publication in the research sample dates back as of 1886. Since that date, the number of publications added every year was raising from a few in 1890s-1920s, through several of them in 1930s-1950s to about 20-40 items in 1960s-1980s. In last 30 years, four periods in the development of the field may be observed. Firstly, a phase of a steady growth in yearly production (from 33 to 208 publications) was noticed between 1990 and 2009 . Secondly, the breakthrough rise in the output (from 208 to 548 items per year) was in place between 2009 and 2012. Thirdly, the stabilization trend was noticed between 2012 and 2015 (at the level of circa 540 publications per year). Finally, since 2015 another period of intensive increase in the number of yearly production has been reported. The peak of this increase was in 2018, when 892 new publications were added to the research field. Summing up, it is worth noticing that physical education is a wellestablished research field with a long tradition. In the $2010 \mathrm{~s}$, it has received an increasing attention of academia which resulted in breakthrough growth in the number of publications indexed in Scopus. The dynamics of the changes in scientific productivity of research in physical education in last 30 years is displayed in Figure 1.
The amassing research output focused on the issues of physical education is distributed over 26 subject areas defined by the Scopus database. Social Sciences, followed by Medicine and Health Professions, are the subject areas grouping the highest number of publications. The United States is the unquestioned leader among the most productive countries. Other major contributors are: the United Kingdom, Spain, Brazil and China. The following universities are reported as the leading research institutions in the field: British Loughborough University, American Ohio State University, Australian University of Queensland as well as Spanish University of Murcia and University of Granada. The institutions from the United Kingdom and Spain are most often represented among top contributors. David Kirk from the University of Strathclyde, the United Kingdom is found to the most prolific researcher. However, scholars affiliated at the United States universities are the most often listed among the most productive authors. Teoriya i Praktika Fizicheskoy Kultury is usually the first choice among quality source titles to publish research findings from the field. Other the most prominent journals include: European Physical Education Review, Journal of Teaching in Physical Education, and Sport Education and Society. Top 10 items in such categories as: subject areas, the most productive countries and research institutions, the most prolific authors and leading source titles are listed in Table 3.

Physical education: Thematic clustering

The keywords of the highest number of occurrence within the research sample are such expressions as: 'physical education', 'human', 'article', 'physical education and training', 'male', 'female', 'humans', 


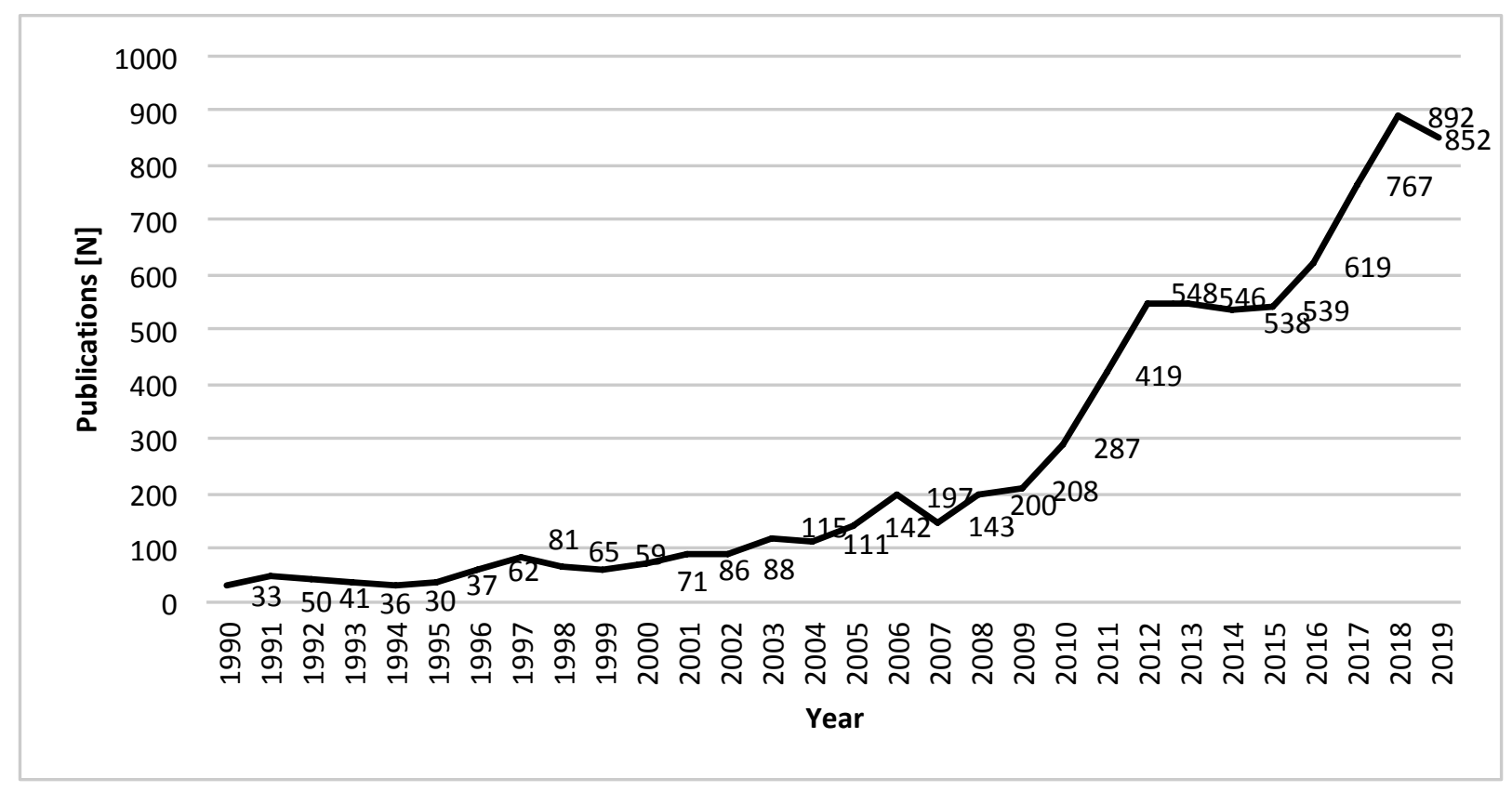

Figure 1. Scientific productivity of research in physical education measured by the number of publications: Source: Own study based on data retrieved from the Scopus (05 January 2020).

Table 3. General publication profiling of the physical education research field

\begin{tabular}{ll}
\hline Category & Top 10 Items (number of publications) \\
\hline Subject area & Social Sciences (5,406); Medicine (4,301); Health Professions (3,848); Psychology (755); Arts and \\
& Humanities (391); Engineering (329); Computer Science (283); Biochemistry, Genetics and Molecular \\
& Biology (162); Agricultural and Biological Sciences (145), Environmental Science (136) \\
\hline Country & United States (2,370); United Kingdom (932); Spain (784); Brazil (707); China (637); Australia (518); \\
& Russian Federation (479); Canada (291); Turkey (220); France (213) \\
\hline Research & Loughborough University, UK (141); Ohio State University; US (111); University of Murcia, Spain \\
Institution & (110); University of Queensland, Australia (109); University of Granada, Spain (107); Federal \\
& University of Santa Catarina, Brazil (95); University of Limerick, Ireland (86); University of Edinburgh, \\
& UK (82); University of Valencia, Spain (81); University of Birmingham, UK (80) \\
\hline Source Title & Teoriya i Praktika Fizicheskoy Kultury (470); European Physical Education Review (336); Journal of \\
& Teaching in Physical Education (335); Sport Education and Society (334); Strategies (301); Movimento \\
& (277); Quest (269); Research Quarterly of the American Association for Health and Physical Education \\
& and Recreation (254); Research Quarterly for Exercise and Sport (230); Physical Education and Sport \\
& Pedagogy (191) \\
\hline Kirk, D., University of Strathclyde, UK (69); Penney, D., Edith Cowan University, Perth, Australia (47); \\
Chen, A., The University of North Carolina at Greensboro, US (41); Richards, K.A.R., University of \\
Illinois at Urbana-Champaign, US (40); McKenzie, T.L., San Diego State University, US (39); Silverman, \\
$\begin{array}{l}\text { S., Columbia University in the City of New York, US (37); Granero-Gallegos, A., University of Almeria, } \\
\text { Spain (36); Beana-Extremera, A., University of Granada, Spain (35); Kulinna, P.H., Arizona State } \\
\text { University, US (35); Xiang, P. Texas A\&M University, US (34) }\end{array}$ \\
\hline
\end{tabular}

Source: Own study based on data retrieved from the Scopus (05 January 2020).

'child', 'students' and 'adolescent'. Top 20 highfrequency keywords and their bibliometric characteristics (including the number of occurrences and links, total links strength and the average publication year) are provided in Table 4 . The item density visualization of high-frequency keywords is presented in Figure 2.

Co-occurrence analysis of high-frequency keywords unveils thematic clusters in the physical education research field. In the map (Figure 3), keywords are grouped due to their relatedness (i.e. the closer they are located to each other, the more related they are. The strongest links between the items are marked with lines. The size of the frames manifests the number of occurrence for a given item.

As visualized in Figure 3, within the physical education research field, there are identified five leading thematic clusters related to: (1) physical education didactics, (2) physical activity of school pupils, (3) physical education 
Table 4. Top 20 high-frequency keywords in the physical education research field

\begin{tabular}{lllll}
\hline Keywords & Occurrences & Links & Total link strength & Average publication year \\
\hline physical education & 4,362 & 138 & 23,055 & 2007.34 \\
human & 1,683 & 135 & 19,474 & 2003,49 \\
article & 1,402 & 136 & 14,850 & 1995,51 \\
physical education and training & 1,321 & 131 & 14,821 & 1994,02 \\
male & 979 & 130 & 13,571 & 2006.25 \\
female & 972 & 130 & 13,476 & 2006.22 \\
humans & 777 & 130 & 11,513 & 2008.19 \\
child & 667 & 127 & 8,924 & 2002.40 \\
students & 632 & 135 & 5,505 & 2011.13 \\
adolescent & 612 & 125 & 8,367 & 2003.24 \\
education & 612 & 137 & 3,470 & 2008.82 \\
physical activity & 608 & 133 & 5,808 & 2012.80 \\
teaching & 580 & 137 & 4,136 & 2010.51 \\
student & 486 & 128 & 6,390 & 2009.30 \\
sport & 468 & 134 & 3,842 & 2004.96 \\
sports & 429 & 134 & 3,079 & 2006.44 \\
motivation & 385 & 127 & 3,193 & 2012.11 \\
exercise & 375 & 128 & 5,096 & 2008.07 \\
adult & 369 & 126 & 4,721 & 2003.40 \\
curriculum & 364 & 130 & 2,913 & 2009.10 \\
\hline
\end{tabular}

Source: Own study based on data retrieved from Scopus and analyzed with the use of VOSiewer (05 January 2020).

of adolescents, (4) human motor competence, (5) physical activity of adults. The items categorized into the identified thematic clusters are enumerated in Table 4. The most prominent keywords, i.e. those with the highest number of occurrences (above 200), are bolded.

Physical education: Emerging topics

The overlay visualization function of VOSviewer enables researchers to assign scores to the items and sort them by the given score. We used this function in order to identify the emerging topics in the research field. We assigned the date of publication as a score to each of the items taken for analysis, then with the use of VOSviewer we generated the map visualizing the average publication year of high-frequency keywords (Figure 4). In the map, the colors range from blue (which corresponds to the lowest value of the score, i.e. the earliest average date of publication), through green to yellow (showing the keywords of the highest value, i.e. the most up-to-date average year of publication).

The overlay visualization shows that the majority of the keywords with the newest dates of publication (visualized in yellow) come from Cluster 1, and they are usually placed in the right flank of the map. Among these most-up-to date keywords there are also some items from Clusters 2 and 3, while Clusters 4 and 5 are not represented (cf. Table 5). In general, Cluster 4 seems to group the keywords with earliest average publication dates (visualized in dark blue), while Cluster 1 is a collection of the most up-to-date issues. In order to complete the picture and to identify the emerging topics in the research field, we searched for the keywords with the newest dates of publication (2014.50 and beyond) and enumerated them in Table 5. Their bibliometric characteristics used for further analysis include: the average publication date, the number of occurrences, links and total links strength.

The analysis of the keywords with the newest publication dates indicates the following emerging topics in the physical education research field: (1) physical education teachers and their training/education (manifested by such keywords as: 'teachers', 'physical education teacher', 'pedagogics', 'teacher training', 'physical education teacher education', 'professional development'), (2) physical education in the tertiary education context ('higher education', 'colleges and universities', 'college physical educations'), and (3) physical education in the secondary education context ('high school'). Moreover, the data show the attention paid by scholars to research rigor, which is manifested by the keywords referring to research procedures or methodology. The methods of study found to be the most often applied in the research field in recent years represent both quantitative approach (cf. 'statistics and numerical data') and qualitative ones (cf. 'qualitative research', 'interviews') as well as experiments ('human experimentation').

\section{Discussion}

The bibliometric review of literature on physical education contributes to mapping the research field and indicates key areas of scientific inquiry. The five thematic clusters in the field have been identified with the use of co-occurrence analysis methodology supported by VOSviewer software. The first cluster is focused around physical education didactics. Among the topics attracting research interest it is worth mentioning the study of teaching and learning in primary physical education through the use of photo-diaries [41] and the review of literature on physical education learning in accordance with the self- 


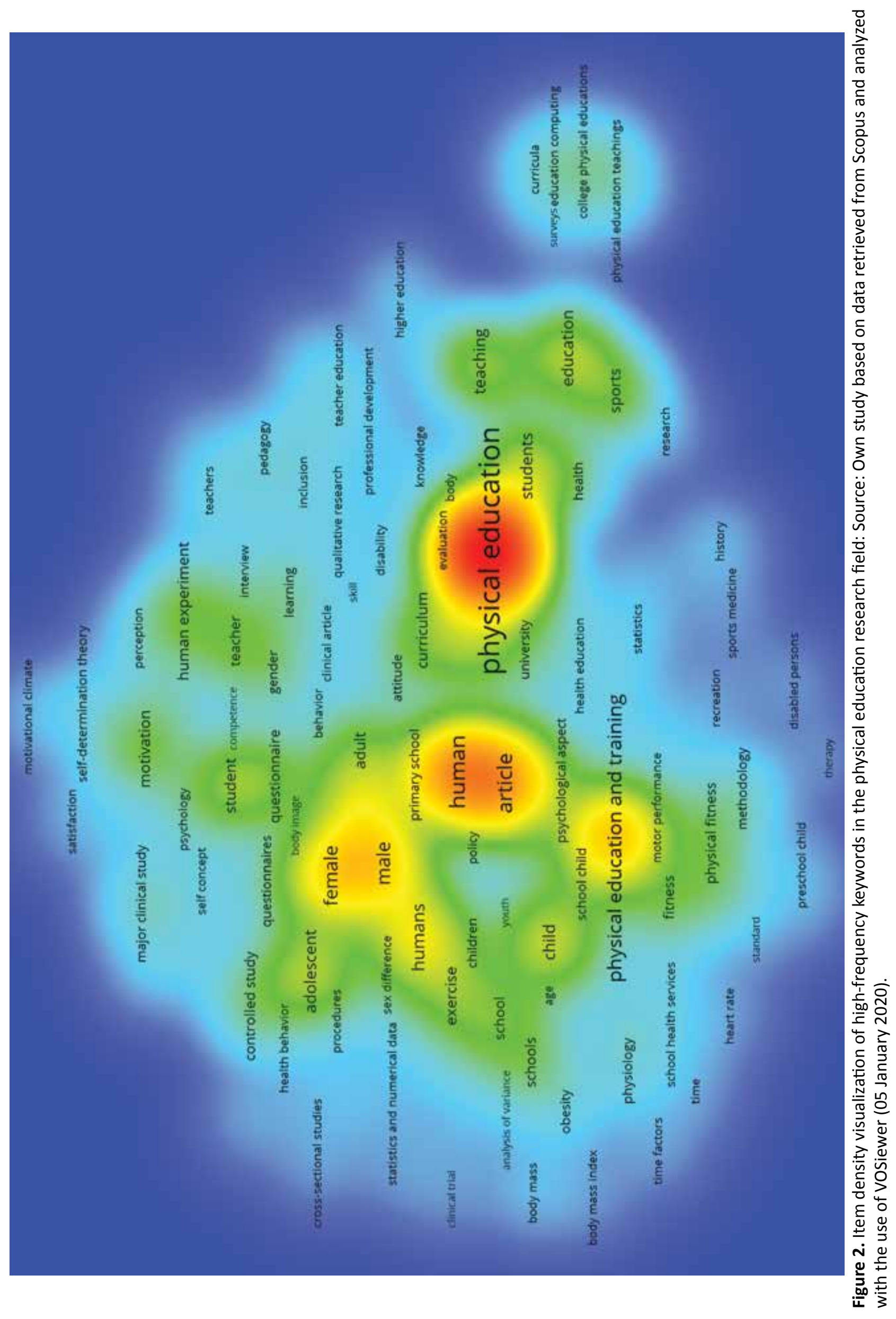




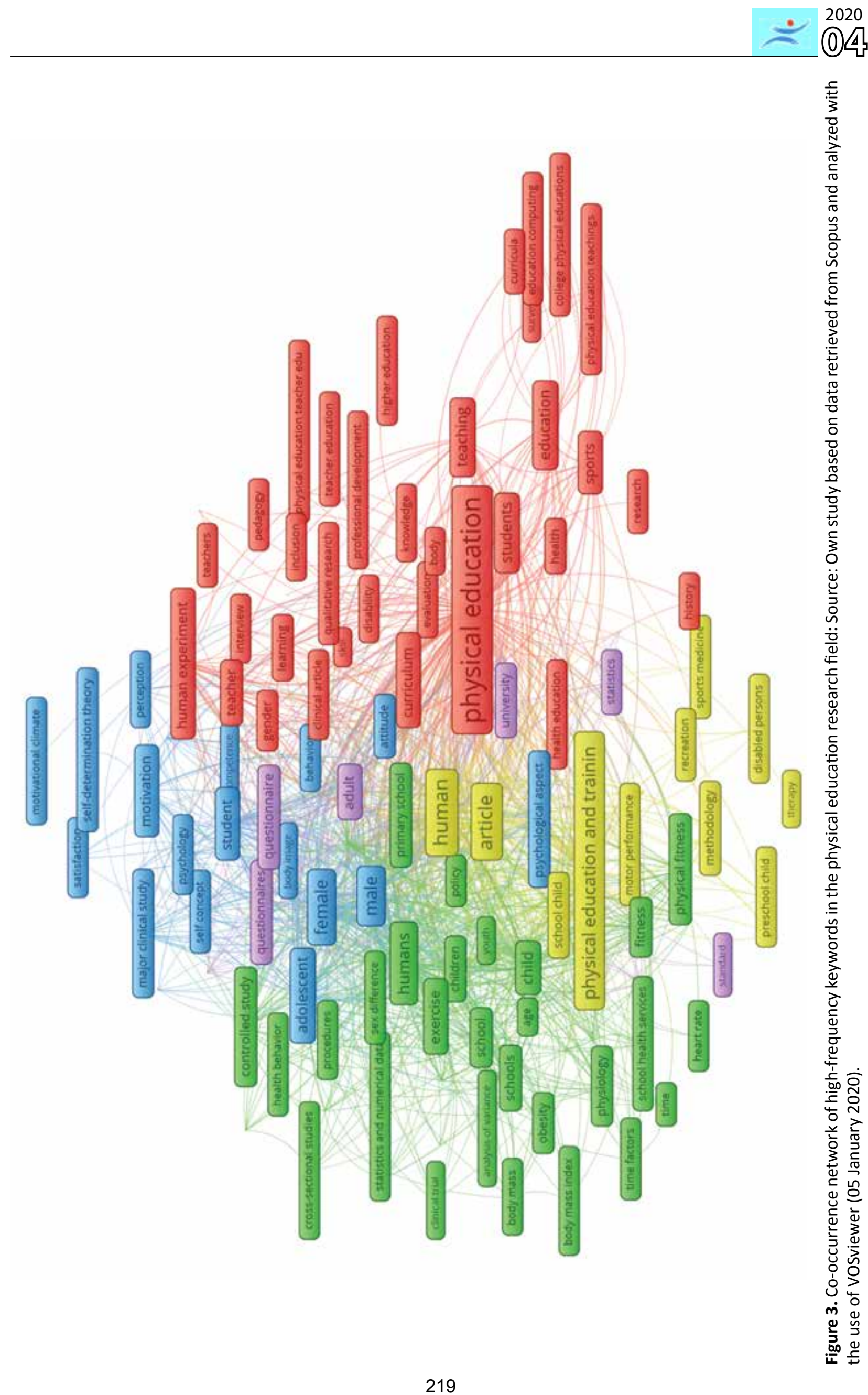




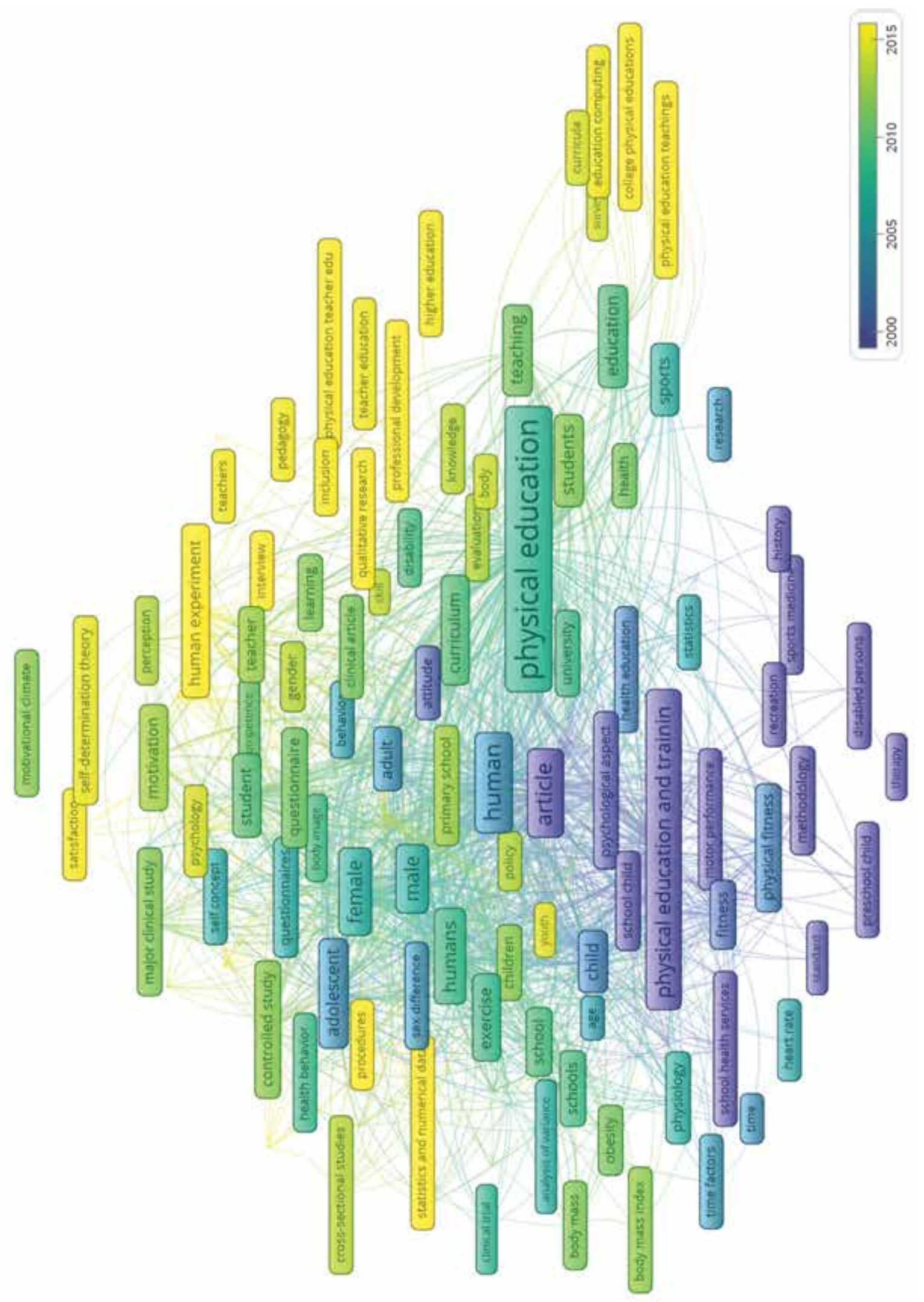

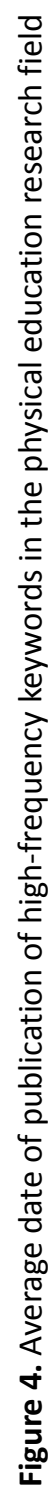


Table 4. Clusters of high-frequency keywords related to research on physical education

\begin{tabular}{|c|c|c|}
\hline $\begin{array}{l}\text { Cluster number/ } \\
\text { label /color }\end{array}$ & $\begin{array}{l}\text { Items } \\
\text { (n) }\end{array}$ & Keywords (occurrences) \\
\hline $\begin{array}{l}\text { Cluster } 1 \\
\text { physical } \\
\text { education } \\
\text { didactics /red }\end{array}$ & 48 & $\begin{array}{l}\text { assessment (59), attitudes (67), body (58), clinical article (72), college physical } \\
\text { educations (65), colleges and universities (71), curricula (113), curriculum (364), } \\
\text { decision making (59), disability (75), e-learning (56), education (612), education } \\
\text { computing (70), engineering education (63), evaluation (57), gender (208), health } \\
\text { (196), health education (100), higher education (90), history (100), human experiment } \\
\text { (362), inclusion (102), interview (93), knowledge (57), learning (202), pedagogics (57), } \\
\text { pedagogy (106), physical education (4362), physical education teacher (52), physical } \\
\text { education teacher education (61), physical education teachers (65), physical education } \\
\text { teachings (99), professional development (72), qualitative research (55), reliability } \\
\text { (99), research (63), skill (51), societies and institutions (71), sport (468), sports (429), } \\
\text { students (632), surveys (48), teacher (320), teacher education (105), teacher training } \\
\text { (100), teachers (113), teaching (580), training (94) }\end{array}$ \\
\hline $\begin{array}{l}\text { Cluster } 2 \\
\text { physical activity } \\
\text { of school pupils / } \\
\text { green }\end{array}$ & 42 & $\begin{array}{l}\text { age (58), analysis of variance (50), body mass (92), body mass index (55), child } \\
\text { (667), children (130), clinical trial (49), controlled clinical trial (53), controlled study } \\
\text { (281), cross-sectional studies (65), cross-sectional study (72), exercise (375), fitness } \\
\text { (278), health behavior (58), health promotion (140), hearth rate (58), humans } \\
\text { (777), longitudinal study (48), motor activity (128), obesity (130), organization and } \\
\text { management (80), physical activity (608), physical fitness (265), physiology (151), } \\
\text { policy (56), primary school (139), priority journal (105), procedures (81), program } \\
\text { evaluation (59), public health (78), randomized controlled trial (81), school (331), } \\
\text { school health service (109), school health services (98), schools (281), sex difference } \\
\text { (113), sex factors (84), statistics and numerical data (57), time (61), time factors (66), } \\
\text { United States (212), youth (48) }\end{array}$ \\
\hline $\begin{array}{l}\text { Cluster } 3 \\
\text { physical } \\
\text { education of } \\
\text { adolescents / } \\
\text { blue }\end{array}$ & 21 & $\begin{array}{l}\text { achievement (73), adolescence (64), adolescent (612), adolescents (122), attitude } \\
\text { (166), behavior (55), body image (51), competence (51), female (972), high school } \\
\text { (139), major clinical study (207), male (979), motivation (385), motivational climate } \\
\text { (70), perception (122), psychological aspect (161), psychology (115), satisfaction (69), } \\
\text { self concept (106), self determination theory (125), student (486) }\end{array}$ \\
\hline $\begin{array}{l}\text { Cluster } 4 \\
\text { human motor } \\
\text { competence / } \\
\text { yellow }\end{array}$ & 16 & $\begin{array}{l}\text { article (1402), child pre-school (52), disabled persons (58), education program (64), } \\
\text { human (1693), methodology (191), motor performance (112), motor skills (93), } \\
\text { normal human (144), physical education and training (1321), preschool child (67), } \\
\text { recreation (57), review (97), school child (175), sports medicine (55), therapy (49) }\end{array}$ \\
\hline $\begin{array}{l}\text { Cluster } 5 \\
\text { physical activity } \\
\text { of adults / violet }\end{array}$ & 12 & $\begin{array}{l}\text { adult (369), attitude to health (75), comparative study (106), faculty (122), lifestyle } \\
\text { (64), questionnaire (293), questionnaires (142), standard (48), statistics (99), } \\
\text { universities (61), university (178), young adult (82) }\end{array}$ \\
\hline
\end{tabular}

Source: Own study based on data retrieved from Scopus and analyzed with the use of VOSviewer (05 January 2020).

determination theory [42]. The second cluster deals with physical education in the school period, focusing, besides school education, on the attitudes of children to physical activity [43] and the determinants of engaging in this activity such as 'being with friends', 'variety in activity content', 'experiencing fun', 'time constraints' and 'opportunity to be outside' [44]. The third cluster identified within the research field relates to physical education of adolescents. Under the umbrella of this theme, the studies e.g. test how keeping a physical activity record in free time motivates adolescents to do physical training [45] and explore how students' motivation influences their performance and engagement in physical education [46]. The fourth cluster concentrates around the issues of motor competence (MC). For instance, Spessato and colleagues [47] investigated "the role of the body mass index (BMI) and motor competence (MC) in children's physical (PA) levels during physical education (PE) classes" (p. 218). Graber et al. [48] tested whether adolescents meet the motor competence standards for a given age, which is not obvious "as roughly $80 \%$ of adolescents fail to meet World Health Organization (WHO) recommendations regarding physical activity" [49]. The fifth thematic cluster identified through keywords co-occurrence analysis relates to physical activity of adults. This area is very much affected by the shift from the industrial economy to the model with the dominating position of the service industry, which resulted in an increase of the number of people working in a sitting position. In the EU projects, physical activity of adults is often considered as a component of sport for all, which is not a very precise statement, understood as a promotion of health lifestyle, including both practicing sports and healthy eating [50]. One of the most interesting studies within this theme is 
Table 5. Bibliometric characteristics of the most up-to-date keywords in the physical education research field (sorted by date of publication)

\begin{tabular}{|c|c|c|c|c|c|}
\hline Keyword & $\begin{array}{l}\text { Average publication } \\
\text { year }\end{array}$ & Occurrences & Links & $\begin{array}{l}\text { Total links } \\
\text { strength }\end{array}$ & Cluster \\
\hline teacher training & 2016.36 & 100 & 99 & 575 & 1 \\
\hline procedures & 2016.35 & 81 & 112 & 1483 & 2 \\
\hline statistics and numerical data & 2016.18 & 57 & 104 & 1081 & 2 \\
\hline pedagogics & 2016.10 & 52 & 85 & 500 & 1 \\
\hline college physical educations & 2016.00 & 65 & 29 & 290 & 1 \\
\hline colleges and universities & 2015.68 & 71 & 32 & 359 & 1 \\
\hline physical education teacher education & 2015.62 & 61 & 40 & 97 & 1 \\
\hline qualitative research & 2015.24 & 55 & 93 & 452 & 1 \\
\hline human experiment & 2015.09 & 362 & 126 & 3,986 & 1 \\
\hline interview & 2015.03 & 93 & 109 & 1,107 & 1 \\
\hline professional development & 2014.96 & 72 & 82 & 285 & 1 \\
\hline high school & 2014.88 & 139 & 120 & 1,684 & 3 \\
\hline physical education teachings & 2014.85 & 99 & 13 & 418 & 1 \\
\hline inclusion & 2014.80 & 102 & 76 & 330 & 1 \\
\hline satisfaction & 2014.65 & 69 & 93 & 796 & 3 \\
\hline higher education & 2014.62 & 90 & 57 & 212 & 1 \\
\hline physical education teacher & 2014.62 & 52 & 45 & 92 & 1 \\
\hline teachers & 2014.54 & 113 & 65 & 248 & 1 \\
\hline
\end{tabular}

Source: Own study based on data retrieved from Scopus and analyzed with the use of VOSviewer (05 January 2020).

a ten-year longitudinal investigation of "the relationship between participation in organized sport and attitude to physical education (PE) during adolescence and physical activity in young adulthood" [51] (p. 139). The role of physical and sport education in developing a positive attitude to physical activity and health behaviors in adulthood was also examined by Bendíková and Dobay [52] and Haycock and Smith [53].

As presented in Figure 5, displaying relationships among the five aforementioned clusters, although Cluster 1 ('physical education didactics') is shifted from the central position to the right edge of the map, its connections with other clusters are the most intensive. An interesting but, when considered thoroughly, logical is a weak relationship between Cluster 1 and Cluster 2 ('physical activity of school pupils'). Such a situation may result from the fact that the aspects of physical education didactics relate more to advanced levels of education, including train-thetrainers aspects. Thus, more connections between Cluster 1 and Cluster 3 ('physical education of adolescents') are observed.

Our study revealed also three 'hot' topics attracting the attention of researchers in recent years (which is manifested by the most up-to-date average date of publication assigned to high-frequency keywords). These topics relate to: (1) physical education teachers and their training/education, (2) physical education in the tertiary education context, and (3) physical education in the secondary education context. Firstly, attention is given to physical education teachers and their training/education. Lambert and Penney [54] emphasize the role of teacher educators in the implementation of new, future-oriented curricula. Cheon et al. [55] test whether becoming "more autonomy supportive and less controlling toward their students could promote students' prosocial behaviors and diminish their antisocial behaviors" (p. 74). Secondly, in regard to physical education in the tertiary education context, the studies focusing on using new technologies in support of education process should be mentioned. Among them, such publications are worth noticing as: "Smart classroom and multimedia network teaching platform application in college physical education teaching"[56], "Research on the inquiry teaching model of men's basketball teaching in college physical education based on network information technology" [57] or "Design and application of university physical education system based on computer aided system" [58]. Thirdly, physical education in the secondary education context is another 'hot' topic attracting attention of scholars recently. In this area, the works of Sparks et al. [59] and Liu and Chung [60] are found among the most cited publications. Sparks et al. [59] focus on researching self-determination theory and its influence on motivation and satisfaction from taking part in physical education classes. The study of Liu and Chung [60] ,presents the development process and initial validation of a measure designed for assessing psychological needs satisfaction in a secondary school physical education context" (p. 101). 


\section{Conclusions}

The study has aimed at assessing the development of scientific production and mapping thematic coverage of research in physical education. First of all, the development of the research field has been discussed with the particular focus given to research productivity in 1990-2019. The study shows that physical education is a well-established research field with a long tradition. It is worth noticing that, in the 2010s, the research field has attracted an increasing attention of academia which resulted in breakthrough growth in the number of publications indexed in Scopus. Secondly, the leading contributors to the research field have been recognized. They are: the most productive country - the United States, the most productive research institution - Loughborough University, the United Kingdom, the most prolific authorDavid Kirk from the University of Strathclyde, the United Kingdom, the first choice source title - Teoriya i Praktika Fizicheskoy Kultury. Thirdly, the thematic areas attracting the most attention of the academia have been identified. The five leading thematic clusters are: (1) physical education didactics, (2) physical activity of school pupils, (3) physical education of adolescents, (4) human motor competence, (5) physical activity of adults. Finally, the emerging topics in the research field have been spotted. In recent years, the particular interest of researchers has been given to such issues as: (1) physical education teachers and their training/education, (2) physical education in the tertiary education context, and (3) physical education in the secondary education context.

The study contributes to better understanding of development patterns in research on physical education. It provides an added value for managing information on scientific productivity in the research field. Through discovering the most productive countries and research institutions, the study maps the research ecosystem and indicates benchmarks for managing research production. Through identifying leading contributors, the study enables researchers to find out potential collaborators among the most prolific authors and make the choice of leading quality journals and source titles for their publications. Through discovering leading thematic areas and emerging topics within the research field, the study points out the issues important both for further research and development of theory as well as for educational and business practice. Therefore, besides the obvious contribution to the research theory, it may be considered as having interesting implications for managing physical education in various contexts.

Discussing the findings of the study, its limitations should be taken into account, too. First of all, only one category of research methods (i.e. bibliometric methods) was employed, which may result in lack of triangulation. Therefore, in the future, the findings of our study should be compared and contrasted with the outcomes of theoretical exploration of the physical education research field, conducted with the use of other types of methods (e.g. qualitative, systematic literature reviews). Secondly, as the whole research field was the object of the study, the differences between the subject areas could have been neglected. Thus, in further research, it would be interesting to discover leading contributors as well as leading and emerging topics in particular subject areas, especially those represented by the highest number of publications i.e. Social Sciences, Medicine and Health Professions. Thirdly, using the Scopus database as the only one source of bibliometric data may lead to some biases (e.g. dominance of publications written in English). Therefore, it would be interesting to replicate the study with bibliometric data retrieved from other databases, including more records in national languages other than English.

Besides the aforementioned recommendations for further research resulting from identified weaknesses of the study, it is important to point out the avenues for researching physical education issues, discovered through exploration of the scientific production in the field. The topics attracting the attention of researchers in recent years discovered in our study seem to be interesting lines of future research. Therefore, we assume it would be reasonable to continue studies on physical education in the context of secondary schools and tertiary education institutions, as well as to explore the issue of education/ training of future physical education teachers. Moreover, due to the COVID-19 pandemic, the use of distance learning techniques for physical education, skills needed to conduct education in such a form and its effectiveness could become another 'hot' issues of scientific inquiry. Certainly, the studies of effectiveness of distance learning techniques have already been studied in the context of professional sport, where there were analyzed cases of players from professional clubs or national teams. Nevertheless, nowadays, because of social distancing requirements, the role of remote physical education at all levels and consequently its attractiveness for further research shows a great potential for growth.

\section{Highlights}

- Physical education is a well-established research field with a long tradition. In the 2010s, it has received an increasing attention of academia which resulted in breakthrough growth in the number of publications indexed in Scopus.

- The amassing research output is distributed over 26 subject areas. Social Sciences, Medicine and Health Professions are the subject areas grouping the highest number of publications.

- The leading contributors to the research field are: the most productive country - the United States, the most productive research institution - Loughborough University, the United Kingdom, the most prolific author - David Kirk from the University of Strathclyde, the United Kingdom, the first choice source title - Teoriya i Praktika Fizicheskoy Kultury.

- Within the physical education research field, there are identified five leading thematic clusters related to: (1) physical education didactics, (2) physical activity of school pupils, (3) physical education 
of adolescents, (4) human motor competence, (5) physical activity of adults.

- $\quad$ Emerging topics in the physical education research field, attracting recently a lot of attention of academia, include the following issues: (1) physical education teachers and their training/education,
(2) physical education in the tertiary education context, and (3) physical education in the secondary education context.

\section{Conflicts of Interest}

The authors declare no conflict of interest.

\section{References}

1. Stothart B. What is physical education? New Zeal J Heal Phys Educ Recreat, 1992;25:7-9.

2. Rosa S, Leta J. Physical education: A multifaceted research field. 12th Int. Conf. Sci. Inf. ISSI 2009. International Society for Scientometrics and Informetrics; 2009. P. 986-7.

3. Whitehead M. Physical Literacy: Throughout the Lifecourse. London: Routledge; 2010. https://doi.org/10.4324/9780203881903

4. Giblin S, Collins D, Button C. Physical literacy: Importance, assessmentandfuturedirections.SportMed,2014;44:1177-84. https://doi.org/10.1007/s40279-014-0205-7

5. Edwards LC, Bryant AS, Keegan RJ, Morgan K, Jones AM. Definitions, foundations and associations of physical literacy: A systematic review. Sport Med, 2017;47:113-26. https://doi.org/10.1007/s40279-016-0560-7

6. Chen C-C (JJ), Holmes ME, Wood K, Ryuh Y, Hodges Kulinna P. Are you better than a 12-year-old student? A pilot study to explore physical literacy in preservice physical education teachers. Phys Educ, 2020;77:130-53. https://doi.org/10.18666/tpe-2020-v77-i1-8798

7. Yi KJ, Cameron E, Patey M, Loucks-Atkinson A, Loeffler TA, Sullivan AM, et al. Future directions for physical literacy education: Community perspectives. $J$ Phys Educ Sport, 2020;20:123-30. https://doi.org/10.7752/jpes.2020.01016

8. Hyndman B, SueSee B, McMaster N, Harvey S, Jefferson-Buchanan R, Cruickshank V, et al. Physical education across the international media: A fiveyear analysis. Sport Educ Soc, 2020;25:274-91. https://doi.org/10.1080/13573322.2019.1583640

9. Fan B, Gan F. Bibliometric analysis of articles on physical education idea published from 2005 to 2009. Geomatics Inf Sci Wuhan Univ, 2010;35:193-5.

10.Hinojo-Lucena FJ, Aznar-Díaz I, Cáceres-Reche MP, Romero-Rodríguez JM. Análisis cientimétrico de las publicaciones indexadas en journal citation reports sobre educación física [Scientometric analysis of the publications indexed in journal citation reports on physical education]. Movimento, 2019;25:e25044. (In Spanish). https://doi.org/10.22456/1982-8918.88722

11.Reverter Masià J, Hernández González V, Jové Deltell C, de Jesus Fonseca T, Legaz-Arrese A. La productividad científica en WoS y el índice $\mathrm{H}$ de hirchs del área de Educación Física en España y Brasil: Productividad y comparación entre países [Web of Science production and the index h Hirsch of physical education teachers: Comparative study between Spain and Brazill. Movimento, 2013;19:125-47. (In Spanish). https://doi.org/10.22456/1982-8918.36582

12.Reverter-Masía J, Hernández-González V, Jove-Deltell C, Fonseca T, Legaz-Arrese A. Producción de artículos en la base de datos Web of Science y Scopus sobre educación física: Estudio comparativo entre España y Brasil [Papers production in the database Web of Science and Scopus about physical education: Comparative study between Spain and Brazil]. Transinformacao 2014;26:114-24. (In Spanish). https://doi.org/10.1590/0103-37862014000200001

13.Prieto-Benavides DH, Palacios A, Cardozo LA, Correa JE, Ramírez-Vélez R. Capacidad científica e investigadora de los profesionalesdeeducaciónenColombia[Scientificandresearch capacity among Colombian physical education professionals]. Apunt Educ Fis y Deport, 2016:19-27. (In Spanish). https://doi.org/10.5672/apunts.2014-0983. es.(2016/1).123.02

14.Barczyński BJ. Ranking of Polish physical education higher schools based on the articles published in 2009-2012 indexed by the Polish Ministry of Science and Higher Education. Arch Budo, 2013;9:273-96.

15.Barczyński BJ. Preferences of the employees of the Polish academies of physical education concerning articles published in Polish journals on sports science and sports medicine, included in the ministerial list. Arch Budo, 2010;6:101-10

16.Barczyński BJ. The first ranking of the scientific units of Polish physical education higher schools based on the monographs published in 2009-2012 indexed by the Polish Ministry of Science and Higher Education. Arch Budo, 2014;10:79-90.

17.Reverter Masiá J, Hernández González V, Jové Deltell MC, Legaz Arrese A. Indicadores de producción de los profesores de educación física y didáctica de la expresión corporal en España en la Web of Science [Production indicators of teachers of physical education and didactics of corporal expression in Spain in Web of Science]. Perspect Em Cienc Da Inf, 2013;18:3-23. (In Spanish). https://doi.org/10.1590/S1413-99362013000300002

18.Hernández González V, Reverter-Masia J, Jové-Deltell C. Producción científica de los profesores del área de Educación Física y deportiva en Cataluña (quinquenio 2005-2009 versus 2010-2014) [Scientific production of the professors of physical education and sport in Catalonia (2005-2009 versus 2010-2014)]. Sport TK-Revista Euroam Ciencias Del Deport, 2017;6:17-24. (In Spanish). https://doi.org/10.6018/280361

19.Lagos Hernández RI, Pérez-Gutiérrez M. Análisis bibliométrico de las tesis de pregrado: el caso de Pedagogía en Educación Física de la Universidad Autónoma de Chile (20072012) [Bibliometric analysis of the dissertations: Physical education degree's case of the Universidad Autónoma de Chile]. Rev Iberoam Educ, 2016;70:181-200. (In Spanish). https://doi.org/10.35362/rie70180

20.Miri M, Kashef SM, Moharamzade M. The application of research methods in physical education and exercise science master's thesis, University of Uremia and Tabriz (13841389). Life Sci J, 2012;9:4376-9.

21.Barczyński BJ, Bak R, Czarny W, Kalina RM. Preferred by Polish students of physical education subject matter and type of bachelor theses in 2008-2010. Arch Budo, 2011;7:41-7.

22.Perrino Peña M, Vicente Pedraz M. Concepciones de deporte y educación física en la revista Citius, Altius, Fortius [Conceptions of sport and physical education in the Citius, Altius, Fortius journal]. Rev Int Med y Ciencias La Act Fis y 
Del Deport, 2012;12:66-82. (In Spanish).

23.Carneiro FFB, Neto AF, Matos JMC, Dos Santos Nazário ME, Dos Santos W. A journal on the move: Contributions to the socio-cultural and pedagogical subfield of Brazilian physical education (2004-2014). Movimento, 2016;22:11-34. https://doi.org/10.22456/1982-8918.59486

24.Cassani Matos JM, Schneider O, da Silva Mello A, Ferreira Neto A, dos Santos W. A produção acadêmica sobre conteúdos de ensino na educação física escolar [The academic production on teaching contents in physical education]. Movimento, 2013;19:123-48. (In Portuguese). https://doi.org/10.22456/1982-8918.34213

25.León-Díaz Ó, Martínez-Muñoz LF, Santos-Pastor ML. Gamificación en Educación Física: un análisis sistemático de fuentes documentales [Gamification in physical education: A systematic analysis of documentary sources]. Rev Iberoam Ciencias La Act Física y El Deport, 2019;8:110. (In Spanish). https://doi.org/10.24310/riccafd.2019.v8i1.5791

26.Gómez-García G, Rodríguez-Jiménez C, Ramos-NavasParejo M. La realidad virtual en el área de educación física [Virtual reality in physical education area]. J Sport Heal Res, 2019;11:177-86. (In Spanish).

27. Wiggers ID, Reis NS, Silva LRT, de Lima MM, Freitas T da C, PraçaTRdeM, etal.Um "raio-X"daproduçãodoconhecimento sobre educação física escolar: Análise de periódicos de 2006 a 2012 [An "X-ray" of knowledge production on school physical education: Analysis of journals published from 2006 to 2012]. Movimento, 2015;21:831-45. (In Portuguese). https://doi.org/10.22456/1982-8918.50517

28.Dos Santos W, Frossard ML, Matos JMC, Neto AF. Avaliação em educação física escolar: Trajetória da produção acadêmica em periódicos (1932-2014) [Assessment in physical education: Academic production in journals (1932-2014)]. Movimento, 2018;24:9-22. (In Portuguese). https://doi.org/10.22456/1982-8918.63067

29.Barreira J, Gonçalves MCR, Medeiros DCC De, Galatti LR. Produção acadêmica em futebol e futsal feminino: Estado da arte dos artigos científicos nacionais na área da educação física [Academic research on women's football and futsal: The current state of scientific articles in physical education]. Movimento, 2018;24:607-18. (In Portuguese). https://doi.org/10.22456/1982-8918.80030

30.Gomes I, Almeida FQ, Marinotte A, Sampaio A, Rossini S. O corpo como tema da produção do conhecimento: Uma análise bibliométrica em cinco periódicos da educação física Brasileira [The body as subject for knowledge production: A bibliometric analysis of five physical education journals]. Movimento, 2018;24:427-40. (In Portuguese). https://doi.org/10.22456/1982-8918.73701

31.PorterAL,KongthonA,LuJ-CC.Researchprofiling:Improving the literature review. Scientometrics, 2002;53:351-70. https://doi.org/10.1023/A:1014873029258

32.He Q. Knowledge discovery through co-word analysis. Libr Trends, 1999;48:133-59.

33. Martinez H, Jaime A, Camacho J. Relative absorptive capacity: A research profiling. Scientometrics, 2012;92:657-74. https://doi.org/10.1007/s11192-012-0652-6

34.Sudolska A, Lis A, Błaś R. Cloud computing research profiling: Mapping scholarly community and identifying thematic boundaries of the field. Soc Sci, 2019;8:112. https://doi.org/10.3390/socsci8040112

35.Sudolska A, Lis A, Chodorek M. Research profiling for responsible and sustainable innovations. Sustainability, 2019;11:6553. https://doi.org/10.3390/su11236553
36.Guo D, Chen $\mathrm{H}$, Long $\mathrm{R}$, Lu H, Long Q. A coword analysis of organizational constraints for maintaining sustainability. Sustainability, 2017;9:1928. https://doi.org/10.3390/su9101928

37.Lis A, Tomanek M. Sport management: Thematic mapping of the research field. J Phys Educ Sport, 2020;20:1201-8. https://doi.org/10.7752/jpes.2020.s2167

38.van Eck NJ, Waltman L. Software survey: VOSviewer, a computer program for bibliometric mapping. Scientometrics, 2010;84:523-38. https://doi.org/10.1007/s11192-009-0146-3

39.van Eck NJ, Waltman L. VOSviewer Manual. Universiteit Leiden; 2018.

40.Donohue JC. Understanding Scientific Literature: A Bibliometric Approach. Cambridge: MIT Press; 1974.

41.Ní Chróinín D, Coulter M, Parker M. "We took pictures": Children's meaning-making in physical education. $J$ Teach Phys Educ, 2020;39:216-26. https://doi.org/10.1123/jtpe.2019-0019

42.Sun H, Li W, Shen B. Learning in physical education: A self-determination theory perspective. $J$ Teach Phys Educ, 2017;36:277-91. https://doi.org/10.1123/jtpe.2017-0067

43.Högman J, Augustsson C, Hedström P. Let's do those 60 minutes! Children's perceived landscape for daily physical activity. Sport Educ Soc, 2020;25:395-408. https://doi.org/10.1080/13573322.2019.1610374

44.Tannehill D, MacPhail A, Walsh J, Woods C. What young people say about physical activity: The children's sport participation and physical activity (CSPPA) study. Sport Educ Soc, 2015;20:442-62. https://doi.org/10.1080/13573322.2013.784863

45.Fullmer MO, Wilkinson C, Prusak KA, Eggett D, Pennington T. Adolescent physical activity and motivational profiles while keeping a physical activity record. $J$ Teach Phys Educ, 2018;37:1-11. https://doi.org/10.1123/jtpe.2017-0072

46.Yli-Piipari S, Kokkonen J. An application of the expectancy-value model to understand adolescents' performance and engagement in physical education. $J$ Teach Phys Educ, 2014;33:250-68. https://doi.org/10.1123/jtpe.2013-0067

47.Spessato BC, Gabbard C, Valentini NC. The role of motor competence and body mass index in children's activity levels in physicaleducationclasses.JTeachPhysEduc,2013;32:118-30. https://doi.org/10.1123/jtpe.32.2.118

48.Graber KC, Woods AM, Castelli D. Motor competence, physical fitness, and participation in physical activity: Do children meet the standards? J Teach Phys Educ, 2007;26:337-424.

49. WeinbergD, StevensGWJM,BuckschJ,InchleyJ,DeLoozeM. Do country-level environmental factors explain cross-national variation in adolescent physical activity? A multilevel study in 29 European countries. BMC Public Health, 2019;19:680. https://doi.org/10.1186/s12889-019-6908-9

50.van Tuyckom C, Scheerder J. Sport for all? Insight into stratification and compensation mechanisms of sporting activity in the 27 European Union member states. Sport Educ Soc, 2010;15:495-512. https://doi.org/10.1080/13573322.2010.514746

51.Kjønniksen L, Fjørtoft I, Wold B. Attitude to physical education and participation in organized youth sports during adolescence related to physical activity in young adulthood: A 10-year longitudinal study. Eur Phys Educ Rev, 2010;15:139-54. https://doi.org/10.1177/1356336X09345231 
52.BendíkováE,DobayB.Physicaland sporteducationasatool for development of a positive attitude toward health and physical activity in adulthood. Eur J Contemp Educ, 2017;6:14-21. https://doi.org/10.13187/ejced.2017.1.14

53.Haycock D, Smith A. Sports participation and health during periods of educational transition: A study of 30-35-year-olds in north-west England. Sport Educ Soc, 2014;19:168-85. https://doi.org/10.1080/13573322.2011.637551

54.Lambert K, Penney D. Curriculum interpretation and policy enactmentinhealthandphysicaleducation:Researchingteacher educators as policy actors. Sport Educ Soc, 2020;25:378-94. https://doi.org/10.1080/13573322.2019.1613636

55.Cheon SH, Reeve J, Ntoumanis N. A needssupportive intervention to help PE teachers enhance students' prosocial behavior and diminish antisocial behavior. Psychol Sport Exerc, 2018;35:74-88. https://doi.org/10.1016/j.psychsport.2017.11.010

56.Zhou B. Smart classroom and multimedia network teaching platform application in college physical education teaching. Int J Smart Home, 2016;10:145-56. https://doi.org/10.14257/ijsh.2016.10.10.14

57.Aimin L, Jianjun L, Ganchen T, Yuanping C, Shaoyong W. Research on the inquiry teaching model of men's basketball teaching in college physical education based on network information technology. Int J Smart Home, 2015;9:169-78. https://doi.org/10.14257/ijsh.2015.9.10.19

58 .Zhong Z. Design and application of university physical education system based on computer aided system. IPPTA $Q$ J Indian Pulp Pap Tech Assoc, 2018;30:681-6.

59.Sparks C, Dimmock J, Lonsdale C, Jackson B. Modeling indicators and outcomes of students' perceived teacher relatedness support in high school physical education. Psychol Sport Exerc, 2016;26:71-82. https://doi.org/10.1016/j.psychsport.2016.06.004

60.Liu JD, Chung PK. Development and initial validation of the psychological needs satisfaction scale in physical education. Meas Phys Educ Exerc Sci, 2014;18:101-22. https://doi.org/10.1080/1091367X.2013.872106

\section{Information about the authors:}

Mateusz Tomanek; (Corresponding Author); https://orcid.org/0000-0002-9527-2513; mtomanek@umk.pl; Faculty of Economic Sciences and Management, Nicolaus Copernicus University; ul. Gagarina 13a, 87-100, Toruń, Poland.

Andrzej Lis; https://orcid.org/0000-0003-4080-4137; andrzejlis@econ.umk.pl; Faculty of Economic Sciences and Management, Nicolaus Copernicus University; ul. Gagarina 13a, 87-100, Toruń, Poland.

Cite this article as:

Tomanek M, Lis A. Managing information on the physical education research field: Bibliometric analysis. Physical Education of Students, 2020;24(4):213-226.

https://doi.org/10.15561/20755279.2020.0404

This is an Open Access article distributed under the terms of the Creative Commons Attribution License, which permits unrestricted use, distribution, and reproduction in any medium, provided the original work is properly cited http://creativecommons.org/licenses/by/4.0/deed.en

Received: 04.05.2020

Accepted: 24.06.2020; Published: 30.06 .2020 